\title{
Preparing Books for Children from Birth through Age Six: A New Children's Reality Approach
}

\author{
Erkan Çer
}

Department of Turkish Education, Faculty of Education, Amasya University, Turkey

Copyright $\mathrm{C} 2016$ by authors, all rights reserved. Authors agree that this article remains permanently open access under the terms of the Creative Commons Attribution License 4.0 International License

\begin{abstract}
Works of literature for children are supposed to give prominence to the child's self. In other words, the level of the works is expected to be appropriate to the characteristics of this demographic. In works of children's literature, the prominence of adults and their worlds along with their ideological, religious, and traditional statements, instead of those of children, indicate that books for children are formed not for children but for adults and their ideologies. This situation reveals an adult's will to shape the child. Merging perceptions, which are unfamiliar to the child's own and pertaining to the adult's world, into books for children may cause a child to take an early step towards adult life. The fact that children find ideologies, behaviors, actions, and senses pertaining to adults' lives, rather than their own, may cause children to feel alienated from their childhoods. Publishing books for children by reflecting perceptions unfamiliar to the children's worlds may cause "adult children" to appear in books for children. This article proposes that works of children's literature should reflect the children's reality. Thus, the child can be an active participant in the process of reading culture.
\end{abstract}

Keywords Children's Reality, Children's Literature, Young Children

\section{Introduction}

As a prerequisite, books for children should be formed according to the children's developmental level [1]. Books for children should also include the "absolute" child and his reality. Formerly speaking, a child's nature, interests and needs, linguistic and cognitive capacity, and perspective on life should be reflected in the design, content, and educational qualities of the book. Hence, a child who has imagination and curious, inquiring, dynamic, enthusiastic, sincere, and creative [2-9] searches for all these characteristics peculiar to his own nature within the design and content of the book presented to him. In this way, the child has the chance to find himself inside the book, activate his concerns, meet his needs, think independently and imagine [95-97]. In such an environment, children may have the opportunity to see their own potential, skills, feelings, and ideas. Books for children should be prepared from this perspective. As stated above, however, merging perceptions which are unfamiliar to the child's own and pertaining to the adult's world into books may cause the child to abstain from reading.

Since the way a child thinks, perceives, and hears differs from that of adults, books that despise or fool them should not be written. In order for works addressing children to arouse the desired impression in their affective and intellectual worlds, the design, content, and educational qualities of works should be determined according to children's developmental levels. Because, a six-year-old child's developmental levels are definitely different from a 12-year-old child [10-14].

The purpose of this article is to propose that the term "child reality" be utilized to present appropriate books to children of different ages and developmental levels. In this paper, the reasons why the concept of "child reality" should be involved in books for children will be discussed. This concept proposes that a child's developmental levels be reflected in books for children. This situation not only means that the child finds his own reality in books but it also contributes to his becoming a habitual reader because of the pleasure of reading.

\section{Child Reality}

Looking at the reality in children's eyes means grasping their inner world, their reality. It is necessary to know about their world, their perspective, and how they defend themselves. Being aware of how a child perceives life and the world allows us to discover his reality [15]. As the "child" is a unique human being, the way a child thinks, perceives, and hears differs from the way adults do [16]. Understanding, caring, and trying to explore the child's inner world may be a way for reaching his reality.

It is essential to regard everything from children's 
perspectives and senses to understand their nature and self-reality. What the child senses indicates his relations with the environment he lives in and how he regards life. Children perceive truths differently from adults and receive facts via a distinct sensibility. This difference between perception and reception stems from their visual, auditory, sensory, imagination, thinking, and intuition abilities at early ages $[11,17]$. Because children have a distinct way of hearing and thinking, they wish to actualize themselves independently through their unique way of sensing and thinking.

Although children are regarded as "little adults" in many periods of life, they are not [18]. They are not the adults of tomorrow, either. Children have idiosyncratic characteristics such as playing, imagination, creativity, and intuition. Most of children have dreams wish to fulfill. They express their feelings and ideas spontaneously and sincerely. They do not have any prejudices in their perspectives on life. In this respect, child reality includes their distinct world and sensibilities and the way children perceive life differently from adults.

Child reality means understanding that children perceive differences as though they were real but not objective at all. Objectivity is not an idiosyncratic child quality. The principles and rules of adult life, its traditional and contemporary values, judgments, stereotyped ideas, etc. are objective criteria shaping adult's thoughts. In early years, children are not able to think objectively as adults do [19]. They expose their subjective feelings and thoughts in interesting lives full of adventures $[95,96]$. Their subjectivity includes sincerity, simplicity, clarity, and being unprejudiced.

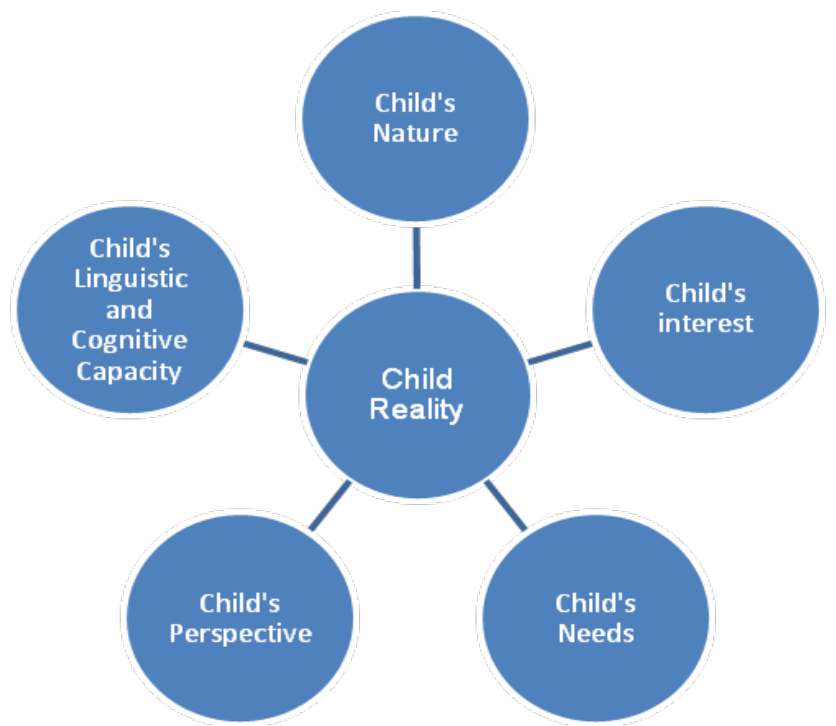

Figure 1. Child Reality

These variables forming child reality provide feedback about the child's inner world. They reveal the child's perspective on life and being human. They establish the elements that affect the child's interests, from a very early age. They help determine the type of book that should be presented to the child by detecting the child's needs. They determine the limitations of the child's affective and intellectual structure. In addition, they reveal the qualities present in his nature from an adult's perspective.

When the concept the child's reality is truly known, the formal, contextual, and educational qualifications of a book can be organized because the most significant limit that separates children's literature from adults' is the qualities of the target demographic. Without determining the child's level of speech and comprehension, interests and needs, perspective, capability of perception, and interaction with life, it is impossible to detect the qualities required in works of child literature. Now that the child's nature, interests and needs, perspective, life experiences, and linguistic and cognitive capacity form his reality, it is necessary that this reality be reflected in children's books. With this in mind, books presented to children should prioritize reflections on children's own realities, otherwise they may negatively affect the child's growth [93].

\subsection{Child's Nature}

Children have realities peculiar to their own natures. They are human beings who like laughing, playing, and enjoying. Their rich imaginary worlds and their motives requiring consistent dynamism are their most specific characteristics. The will to experience adventure and exploration through the sense of curiosity are fundamentals in their lives. The power of imagination frees them from the limitations of real life; children explore a new world in their minds using words, symbols, and images with the aid of the power of imagination. They can shape this new world as they wish; create new ideas in it and find creative solutions to problems. They care about excitement and enthusiasm for how they act and what they do. All these characteristics show that children attribute values and senses to life and the world differently from adults.

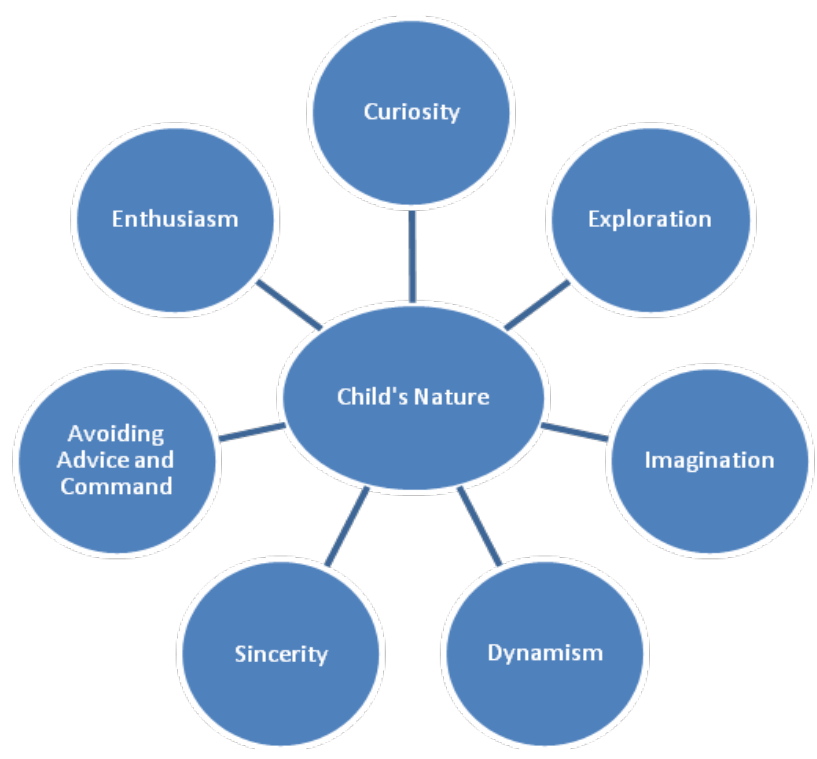

Figure 2. Child's Nature 
Children's personal sincerity, curiosity, effort to understand the unknown, their desire for exploration, creativity, dynamism, enthusiasm, and dislike of advice and orders are due to their natures. Thus, uncovering all aspects of the child's distinct nature may help determine the qualities of the book to be created for him.

\subsection{Curiosity and Exploration}

Among the most basic reality of a child's nature is curiosity [20]. Children need to seek answers to the questions in their minds. Curiosity leads children to question, think about new ways of doing things, and develop and mobilize various perspectives [21]. A curious child questions the world around him and produces his own enthusiasm. This makes the world a game to be explored. The child wants to establish a relationship with entertaining entities and objects leading him to be curious as well [22]. In other words, curiosity leads him to set out on an adventure to explore mysteries [23]. The child seeks answers to problems by developing his limited experiences through adventure.

Due to their nature, children want to have fun, play games, and explore new things [15]. The child's will to find out the "why" makes him an active participant in the process of exploration. The fact that a child acquires knowledge and ability by taking on the responsibility of hearing and thinking is due to his sense of exploration. Through this process, the child inclines to research in an effort to render the world meaningful. The child in the process of examining and researching discover his skills, abilities, and potentials [24]. The experience that the child gains through the researching process arouses an insatiable desire for exploring. This desire uncovers the mysteries of the world, renders the child's environment more meaningful, describes human existence, gives the child enthusiasm, helps him gain knowledge and skills, and sets him out on an adventure because, for a child, learning means exploring knowledge. Therefore, the desire for exploring through curiosity and experiencing an adventure are the fundamentals of their lives.

\subsection{Imagination and Dynamism}

The child perceives the universe in which he lives through his imagination and senses. Children's rich imaginary worlds are their most unique characteristics. It is the power of imagination that frees them from the limitations of life [25]. Children discover a new world that already exists in their minds through words, symbols, and images. In this world, they generate countless ideas with the aid of their imagination. The power of imagination takes children beyond real experiences, giving them initiative and originality. It also helps them bond with a book intuitively and sentimentally. Furthermore, it promotes the opportunity for children to make imaginary friends by helping them express their feelings and ideas [26-29]. It offers them the skill of creative thinking and generating. It charges them with a different responsibility in thinking, helping them reach a realm that has not been created or discovered yet.

Children's desires, feelings, ideas, and beliefs vary and evolve in childhood [30,31]. In these years, children's affective and intellectual worlds are dynamic since they constantly evolve and cycle. Children's feelings vary to an even greater degree, especially in early childhood [3,32]. Hence, children's feelings and ideas are constantly changing through new experiences [33,34]. In these respects, children should be considered social and dynamic beings [35].

From the modern standpoint, childhood is a dynamic and changeable period [36], which proves that children's feelings, ideas, and imaginary worlds are also dynamic and changeable. The child always wants to show his joy and love, and reveals his worries about a phenomena he is unable to comprehend [37]. Hence, it is necessary for cohesion between the books to be presented to children and dynamism in their affective and intellectual worlds.

\subsection{Enthusiasm and Sincerity}

Life means excitement and enthusiasm for a child. Therefore, it is important to take note of these feelings because they mobilize the child and direct his actions [38]. The child begins exploring when he is engaging in an exciting action. On the other hand, repressing enthusiasm may cause children to have negative attitudes towards a book they may encounter for the first time. Therefore, a child needs a book to arouse enthusiasm [3], because this will result in a positive interaction and begin his exploration. In other words, action and enthusiasm lead the child into adventure because it is in the child's nature to seek excitement [39].

Every action and behavior leads children to have new enthusiasm, worries, and joys because children are able to anticipate how a fact or situation may affect them. In particular, children sense the excitement of new experiences and initiatives and, therefore, like to engage in them.

Children perform all actions as a result of their feelings. Therefore, there is no interaction that is not accompanied by a feeling. Since children's interactions with their environment are constant, their feelings are consistent. Thus, a child sincerely reflects his feelings without constraint, that is, he exposes his affective reactions clearly and sincerely when he is pleased or afraid.

Children have a warm and sincere sensibility when they need to express their feelings and thoughts. They start interactions with life by reflecting their true inner conditions $[14,40]$ because children are beings who are genuine, spontaneous, and express what they think without limitations. Children bond more with books and adults that seem warm, sincere, and sensitive to them. In this respect, feeling the sincerity and clarity in a child's nature is the most important aspect of interacting with him. 


\subsection{Avoiding Advice and Command}

Family characteristics may influence social, psychological, and intellectual development of children [41-43]. Addressing children with sentences full of rules and orders is against their nature because they want to actualize themselves freely. Telling them what to do or not do inhibits them from thinking about cause and effect relationships. During the process of educating and teaching, rules and commands may not let children think freely, imagine, and actualize themselves. Some of the most significant inhibitions of children's critical thinking skills are commanding and advising them and setting rules against their needs for expression, response, and evaluation. Other than advice and commands, scolding and humiliating statements may cause the child to be introverted. Hence, parents should permit children to use their own intuitions in developing their imagination and skills [44]

An approach fixed by rules and commands means disregarding and not caring about the child. This approach may cause the child to remain stuck in polarized views of good and bad, right and wrong, and positive and negative. Moreover, adopting an approach that is incompatible with the child's nature may impede his multi-minded thinking. Commanding and advising keep the child under pressure and prevent him from enjoying, having enthusiasm, and exploring the world. These practices and exposing the child to adults' desires may make him aggressive, leading to the possibility that the child might develop undesirable personality traits.

\section{Child's Needs}

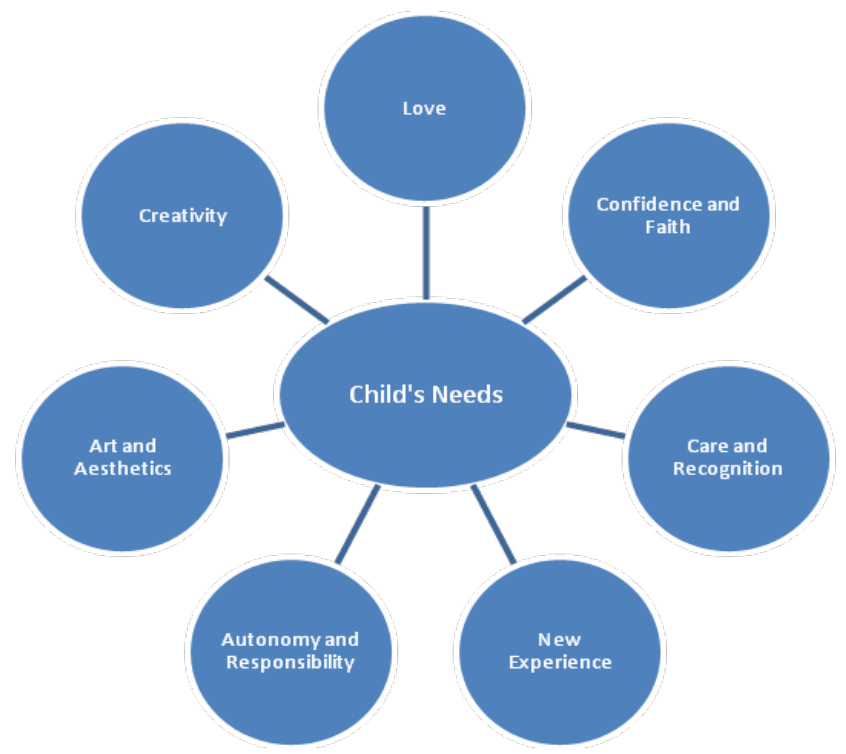

Figure 3. Child's Needs [48]

Need is a broad term that consists of human beings' physical, affective, social, and cognitive desires to socialize and sustain their lives[45]. Children's physical, affective, social, and cognitive needs should be satisfied in early childhood [46] because, when a child's needs are satisfied in this period, he may develops a positive self-image, tends to socialize with other children [47] feels more relaxed, and gets ready to explore and actualize himself by using his potential. In this respect, need plays a crucial role in a child's relationship with the world.

Only satisfying a child's physical needs may not help the child expand his affective and intellectual world, imagine, socialize, get ready to explore, research and examine, have self-esteem and respect others, attach to others with love and confidence, and actualize himself by using his potential [94]. Thus, affective needs must be satisfied so that he can develop life skills. A child's need for love and confidence, knowing and recognizing, being cared for and approved of, taking responsibility and having new experiences, self-determination and responsibility, creativity, art, and aesthetics help him develop his skills. After these needs are satisfied, the child will have self-esteem.

\subsection{Child's Need for Love}

Love forms the basis for children's attitudes and behaviors towards their environments and nature. Children, especially in their early years, approach human beings and nature with love. Children should grow up with love. Therefore, the first need to be satisfied is love $[49,50]$ because children who grow up with love become sensitive to all constituents of this emotion. Love improves their socialization, identification with others, and their desire to search and examine the world. In addition, they count on books and the people around them to a greater degree. Thus, children should have an environment that is safe and full of love [51].

The need for love lasts for a lifetime. Love must be constantly satisfied, like hunger and thirst. Beginning particularly from the early years, a child needs care and love, unconditional positive regard, respect for his personality, and to learn to share. Therefore, in order to ensure a childhood that fosters the development of children's skills and abilities, they must form loving and reassuring relationships with others during crucial learning stages; this results in children being ready and happy to learn throughout childhood. Discovering those skills which already exist in their nature is the responsibility of adults and books, and this can be accomplished through love, so that the process of learning is efficient and happy for children.

\subsection{Child's Need for Confidence and Faith}

Children want to trust and have faith. Confidence and love form the basis of the relationships that children establish [48]. They need to feel safe to uncover their potential [52]. To love children and to tell them that we care about them develops their self-confidence. Children need imaginary and real environments in which they can feel free because this will make them more confident as they set out on an adventure.

Satisfying children's need for confidence helps them form positive relationships with other people and have better 
social skills in the following years [53]. Additionally, satisfying this need provides them with intrapersonal (affection, intimacy, love) and interpersonal (social status, respect) satisfaction and helps them achieve their goals and overcome problems [54,55]. However, when adults and books constantly impose feelings of failure and incompetence upon children, their confidence may be shaken. Hence, not satisfying children's need for confidence may cause them to approach their environment suspiciously.

Children's relationships are directed by their needs for love and confidence. For this reason, children treated by adults in a loving, reliable, and predictable manner also react to their environment with greater confidence. If loved and cared for, a child develops confidence. A more confident child looks for his feelings to be reflected in the books he reads because children are beings who are curious, enthusiastic, eager, and trusting. Hence, children's needs and goals must correspond to the books to be presented to them because they look for a trustworthy human or a character that is open to change and development, in a reassuring and sincere environment, in order to foster discovery.

\subsection{Child's Need for Care and Recognition}

A child wants to see and hear that he is cared for and appreciated, which will improve his self-outlook, namely his self-esteem [56]. It is necessary to care about and appreciate anything that concerns them, makes them think, happy, or worried. It is also essential to help them express themselves and take on the responsibilities of thinking and imagining. In particular, if the child knows that he is listened to, it makes him realize that he is cared for. An evasive approach, however, causes the child to feel neglected and worthless. Hence, caring about the child is one of his most basic needs.

Helping children take on the responsibility of thinking and imagining shows the care and value that we have for them. When children are cared for, they take up creative activities to actualize themselves. They are supposed to be aware of the importance of their efforts. Actions which children perform by thinking, imagining, and taking on the responsibility of learning are of vital importance to children.

Including the child in problems and cooperative thinking as well as sharing his excitement and approving when he gives an opinion are positive attitudes that meet the child's need for learning. Therefore, an adult or a book is expected to help a child feel cared for and appreciated with a viewpoint appropriate to the child's nature.

Seeing the child from an adult's perspective and counseling him to live according to adults' ideas, rules, and philosophy of life disregard the child's feelings and ideas, as a child has his own nature. Books prepared without taking this into consideration may hinder him from taking on responsibility, becoming efficient, stating his opinions, and thinking critically and creatively. A child needs imaginary and real environments in which he should feel cared for and appreciated.

It is essential to care about a child's feelings and ideas, yet children often come into a world full of insensitivity and judgments, where what they feel or think does not matter to adults. What matters is how rules and commands, which are inappropriate to the child's nature, are applied. Advice, commands, and rules have negative effects on a child's growth. Children want to express their joys and worries sincerely. If this sincerity is repressed or inhibited, they cannot comfortably express their feelings.

\subsection{Child's Need for New Experiences}

Experience is based on the interaction between a child's intrinsic and extrinsic world, in which the child is active, and in which learning processes and knowledge are efficiently structured [57]. Therefore, children's experiences should never be ignored because experiences form learning. They help children prove their skills by taking on responsibility for hearing and thinking.

Children need new experiences that arise as a result of curiosity and discovery because children restructure their knowledge and develop their skills using their experiences. Children have an incredible ability to learn from experiences [58]. Therefore, adults should not ignore the significance of children's experiences [59]. Furthermore, experiences giving children the chance to learn on their own help them communicate effectively, share, take on responsibility, and reflect their own feelings and ideas. Hence, a child needs imaginary and real experiences to be able to take on the responsibility of hearing and thinking; to be efficient; to satisfy his will to know and recognize; to experience feelings of success; and to socialize and share.

Children desire to explore, examine, and learn about the environment around them, which leads to many new experiences from their early years. These experiences present children with an efficient environment in which to reflect their feelings, ideas, actions, and behaviors. In this type of environment, children take on the responsibility of learning by themselves and endeavor to achieve their own success. Positive contributions to children's lives in the early years help them gain experience, make their lives full of adventure, and help them become socially healthy and successful individuals.

\subsection{Child's Need for Autonomy and Responsibility}

Children want to be free in their behaviors and attitudes. They want to imagine and think freely, express their thoughts and feelings, play games, and enjoy life [60]. For children, not reading, writing, drawing, and playing means not being able to imagine, enjoy, and think. Children need to be free to be able to explore their environment and become more sociable. Children who cannot express their feelings freely and face violence and pressure by an adult or a book become reluctant to research and investigate because their wills and actions are hindered by violence and pressure, and their confidence decreases. Children who do not feel confident in themselves and their environment do not want to take part in 
new experiences and initiatives. These children become reluctant to express their feelings and ideas freely by not taking on the responsibility of listening and thinking.

If children express their own feelings and ideas freely and perform their actions without pressure and hindrances, this may positively affect their autonomous selves $[61,62]$. Keeping the child away from the actions and behaviors he enjoys may cause him to be unable to express his feelings adequately. In this sense, lack of affective interaction between the child and adult or stimulus causes him to fail to build good relationships; he become an introverted individual who is weak in social skills and his linguistic skills are also negatively affected [63]. In addition, giving children responsibilities they cannot carry means that they cannot satisfy their need for freedom. Hence, it is fundamental that adults give them the opportunity to speak freely, express their thoughts and feelings, imagine, and take on the responsibility of thinking.

\subsection{Child's Need for Art and Aesthetics}

At an early age, it is necessary to include children in the artistic education process [64] because there is no more useful instrument than art to help a child know about his environment, express himself, develop his way of thinking, imagination, and creativity, gain sensitivity, train his senses, and gain aesthetic experiences. Therefore, it is essential to give children artistic books to enrich their creative thinking, help them express their own feelings, help them evaluate certain phenomena from their own perspectives, and help them develop their affective qualifications. Through these books, children can gain sensitivity to human beings, life, and nature.

Art is the "language of thinking" for children. Hence, artistic education is an important part of a child's process of thinking and expressing. The world of the child who can paint the sky red or a tree blue; draw eyes, eyebrows, and a nose on the sun; and put a smiley face on the moon is immensely free and original. The child should both sense the joy and the excitement of the process of creation and get the opportunity to express himself. Besides, art helps the child develop his distinct skills in imagination, creative attitude, and aesthetic sensibility. Through art education, children interact with their environment using their senses, interpret their perceptions in their cognitive worlds, and show their unique abilities. Furthermore, art develops a child's attention, perception, imagination, intuition, and comprehension skills.

Since taste and the concept of art are derived from aesthetic sense in the early years [65], the more a child develops an aesthetic concept, the more effective and intense his relation with art becomes; however, aesthetic sense does not develop on its own. It is based on the quality of the artistic stimulus. Hence, every child needs creative stimuli and activities to express himself in an interaction sourced from his nature. As creativity and aesthetic appreciation are critical for human beings, it is important for a child to be informed and made sensitive about art early on because senses like seeing, hearing, touching, and smelling become dynamic, nourished, and strengthened thanks to artistic conceptions. For the positive development of these senses, it is recommended that a child's sense of artistic expression be nurtured from an early age.

\subsection{Child's Need for Creativity}

Creativity helps children research, explore, examine, and evaluate [66] and also exposes the flexibility, originality, and sensitivity in their thinking. Creativity makes the child excited to experience a new action. The process of creating strengthens the child's incentive to achieve. Curiosity and originality contribute to various abilities, phenomena, and qualifications such as intuition, vision, syllogism, trial, research, testing, finding, getting rid of clichés, and reconstructing.

Among the most significant characteristic of early childhood is that children are creative in this period [67] which helps them research, explore, and examine. Through this process, the child senses his power of imagination, curiosity, thinking, solving problems, originality, and productivity. Moreover, the child could express himself clearly, be inclined to adventure, good at problem solving, curious, eager to notice differences, original in thinking, and open to biased thinking. Therefore, the child should be presented with artistically qualified books to help develop these skills.

\section{Child's Interest}

Interest is a motivational element allowing the child to concentrate [68], and an affective variable helping him focus [69]. In addition, interest is a prerequisite for him to begin exploring, interacting, forming relationships, and proving his skills. Interest, which can change according to both personality and environmental stimuli, activates the child cognitively, affectively, and dynamically. Children's individual interests allow them options they like and enjoy ([70]. The fact that a child enjoys, likes, and establishes a rapport with objects helps increase his interest. A child's dependent interest varies according to what grabs his attention. The auditory and visual sides of the stimulus and its design, mobility, size, and colors attract the child's attention. Different, new, amazing, discoverable, mysterious, or extraordinary stimuli are dependent variables revealing the child's interest. Therefore, it is necessary to include stimuli that can grab children's attention throughout their early years.

A child who belongs to the $0-6$ age range tries to explore the unknown by focusing on the visual, dynamic, auditory, tactile qualities, and size of a book presented to him. In other words, children, depending on age and growth level, focus on books in different sizes; tactile surfaces with different qualities; auditory objects composed of various repetitive beats, tones, rhythms, and melodies; dynamism produced by 
actions and behaviors; and visuals drawn clearly and attractively with bright, contrasting, plain, and vivid colors. In addition, children belonging to this age range like supernatural, attractive, new, mysterious, curious, extraordinary, entertaining, amazing, funny, unusual, interesting, and exciting books, and an unexpected and new situation, incident, environment, experience, and elements. Thus, if the stimulus is a book, these qualifications must be intertwined with the formal and contextual properties of the book.

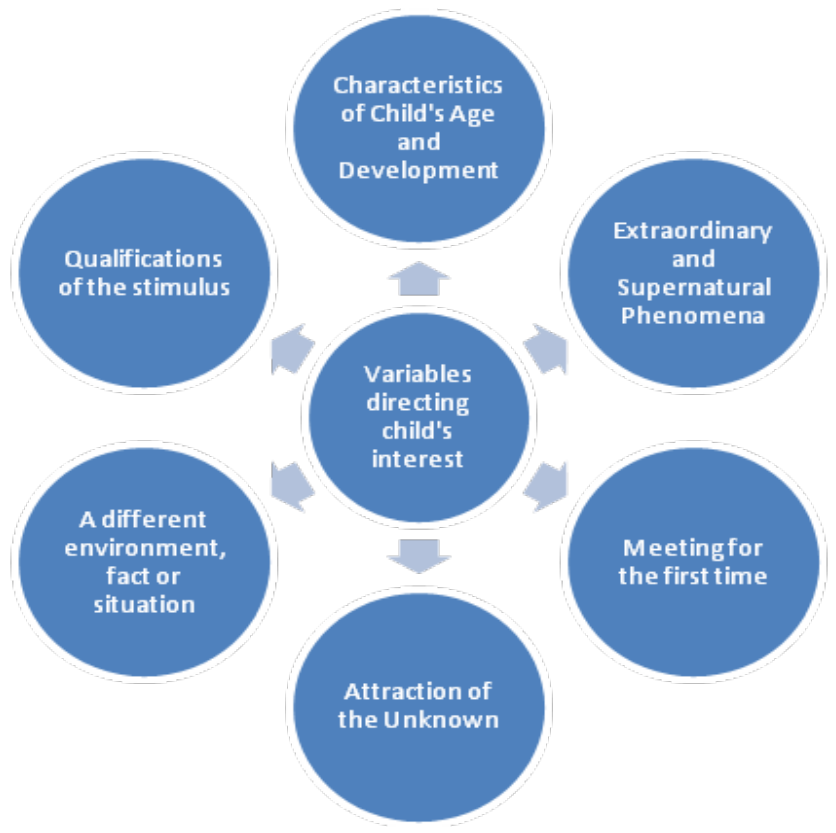

Figure 4. Variables directing the child's interests [15,70-73]

\section{Child's Perspective}

Perspective taking is a term and subcomponent of empathy [74] and affects how we perceive life [16], the way we express our feelings and ideas $[15,75]$. Our perception determines our relationship with our environment [76], our life style, which changes as we grow older, and how we perceive ourselves [77-79]. Children, like adults, try to comprehend life and human beings through their affective and intellectual world. For this reason, children's feelings, ideas, interests, and perception styles are different from adults'. A child's perspective is affected by his ability to perceive, his linguistic and cognitive capacity, the way he hears and thinks, his experiences, his relations with his environment, his power of imagination, and social and cultural environment.

The term childhood is, in many ways, the antonym for adulthood. Children are curious compared to adults; they interpret facts with their own perspective and idiosyncratically attribute meaning to facts. Children trying to render the world meaningful through their own perspective [19] want to sense facts by adding their own imagination. Hence, children's feelings, ideas, interests, and ways of perceiving life are different from adults'.

Children perceive the world and the environment around them based on their subjective criteria and establish relationships through this viewpoint. The world, to them, is at first a series of complexities that have no relationships with each other. As they grow up, they learn to establish functional relationships with the objects of the world, thus, they grasp the ideas and objective criteria of the adult world. The fact that children have idiosyncratic subjective criteria and evaluations, and that they do not perceive life through adults' objective criteria and evaluations reflect the structure of their perspective.

Table 1. The way adults and children think

\begin{tabular}{|c|c|}
\hline The Way Adults Think & The Way Children Think (0-6) \\
\hline $\begin{array}{c}\text { 1. Objective Criteria and } \\
\text { Evaluations } \\
\text { (Principles and rules, traditional } \\
\text { and modern values, dictating } \\
\text { attitudes and statements, } \\
\text { stereotyped ideas, etc.) }\end{array}$ & $\begin{array}{c}\text { 1. Subjective Criteria and } \\
\text { Evaluations } \\
\text { (Idiosyncratic values, free as can } \\
\text { be, sincere and intrinsic, etc.) }\end{array}$ \\
\hline 2. Reasonable and Logical & $\begin{array}{c}\text { 2. Interpreting facts arbitrarily, } \\
\text { instantly }\end{array}$ \\
\hline $\begin{array}{c}\text { 3. Multi-minded and } \\
\text { Sophisticated Ideas }\end{array}$ & $\begin{array}{c}\text { 3. Single-minded, Plain and } \\
\text { Unsophisticated Ideas }\end{array}$ \\
\hline 4. Social & 4. Egocentric \\
\hline 5. Abstract & 5. Concrete \\
\hline 6. Realist & 6. Imaginary \\
\hline
\end{tabular}

Source: Piaget $[16,19,80]$

A child in the $0-6$ age range is not able to see life through objective criteria and evaluations. The way he perceives life is subjective and he cannot generate objective and reasonable ideas as adults do. He conveys his feelings and ideas sincerely and freely, during which he ignores any objective principles and rules, criteria and evaluations, dictating attitudes and statements, traditional and modern conceptions, and stereotyped ideas. Children arbitrarily interpret facts and generate unsophisticated, plain, and bare ideas. Also, children do not need to keep what they think secret and they are never anxious about being understood by others. In this respect, there is a clear-cut difference between adults' thinking structures, which are generalized but also confidential when necessary, and children's thinking, which is always expressed freely [19].

In his early years, the child interprets facts through his own perspective and attributes subjective meanings to them. The child trying to render the world meaningful through his perspective struggles to sense facts using his extrinsic world and he can bring a new perspective on similar facts through imagination and generate solutions to problems [81]. Therefore, contrary to the realist ideas of an adult, the child conveys his ideas by including his extrinsic world in his perspective.

The fact that a child in the $0-6$ age range is egocentric with his ideas and feelings; assumes himself to be at the center of facts; tries to explain any facts subjectively; lacks a sense of sharing; interprets everything subjectively; and the fact that 
he cannot distinguish between "some and all" reflect the child's perspective in this age range. Also, the fact that the child's perspective is egocentric determines the qualities of the books to be presented to him. In this period, children's books should direct them to cooperate and share in terms of concepts such as sense, ideas, and perspective.

Children expose their feelings, ideas, joys, anger, astonishment, excitement, sorrow, frustration, inner conflicts, etc. through their own perspectives [80] fact that they know little about the world leads them to research and examine [82]. They regard this mysterious world with eyes trying to understand [15]. They ask questions in order to figure out the absolute world. Children are happy when they find answers. When they are successful, their eyes get brighter. Plainly speaking, the way they perceive the world reflects upon their actions and behaviors.

Children's perspective, that is, their perception of life, can be seen as they endeavor to know and understand their selves and lives with curious eyes; include their extrinsic worlds in their lives; take part in various entertaining adventures; play games full of excitement; ask questions; fall and rise; sing ardently; display idiosyncratic creative actions, etc. [83]They expose their distinct sincerity and spontaneity while performing these actions and behaviors. They have neither complicated reasons behind their questions nor intertwined ideas nor certain principles. The versatility of adults' lives is unfamiliar to children's lives. They ask questions for absolute knowledge and recognition.

\section{Child's Linguistic and Cognitive Capacity}

A child's cognitive capacity is formed by his linguistic, affective, and biological competence; his vocabulary; visual texts created in colors and lines; linguistic texts; intelligence; and social and cultural environment $[15,19,64,76-78,80]$. Along with these variables, individual differences also affect a child's cognitive capacity in both a positive and negative sense because children who are at different linguistic, auditory, and physical stages differ in their cognitive capacities. The fact that every child differs in intelligence, growth, and maturation levels shows that their linguistic, physical, and auditory competences are different, too.

The development of a child's cognitive capacity parallels his linguistic development. Hence, the vocabulary a child acquires affects his cognitive capacity. As his vocabulary expands, his cognitive capacity expands as well because words lie beneath ideas and allow children to know about life and establish purposeful relations in life. A child without adequate words is limited in his cognitive receptions when thinking. This is a fact in his early years [16]. As the child's cognitive competence lacks reception, it is necessary to approach him through colors and lines because they render concepts clear, distinctive, and introductory. A child's cognitive capacity changes depending on this process.

When linguistic and cognitive development proceed equally [17], a child's interactions with language provide a basis for a child to perceive, sense, receive, grasp, think, evaluate, classify, compare, match, and set cause and effect relations, etc. [19] In other words, the child's linguistic memory enhances and expands his comprehension, thinking, sensing, and perception, that is, the way a child perceives life is an expression of his linguistic acquisition. For this reason, the more a child's vocabulary expands through appropriate books, the more his cognitive capacity and the way he perceives life also expands.

The awareness of a child's linguistic development gives us feedback about his cognitive capacity. When we identify children's vocabulary according to their age range, we obtain clues about their cognitive capacities. A two-year-old child uses 50 or more words and understands most of them. A two and a half-year-old child uses over 200 easily identifiable words, yet the structure of the sentences that the child makes and the way he pronounces words have childish characteristics. A three-year-old child knows around 300 words, uses language with great enthusiasm and he is interested in using new words. A four or five-year-old child's vocabulary consists of almost 1500 words. A six-year-old child's vocabulary is over 2500 words [ $17,85-87]$.

The innate biological competence of a child also affects his cognitive capacity. If the mother undergoes oppressed, stressed, or negative situations from pregnancy to birth, this may result in negative side effects on the child's cognitive, auditory, personal, and linguistic development [77] In addition, the fact that the child cannot meet his needs for love, confidence, care, belief, autonomy, affection, etc. may indirectly affect the child's cognitive capacity [88] The more the child is deprived of stimuli, the more his extrinsic world and cognitive capacity are restricted [89] because a child facing qualified stimuli can cope with problems using his extrinsic world effectively, generate various ideas, explore, enhance his creativity, and most importantly make an imaginary friend. Along with all these variables, the fact that intelligence corresponds to mental abilities and a child expands these abilities through environmental stimuli can contribute to cognitive capacity. 


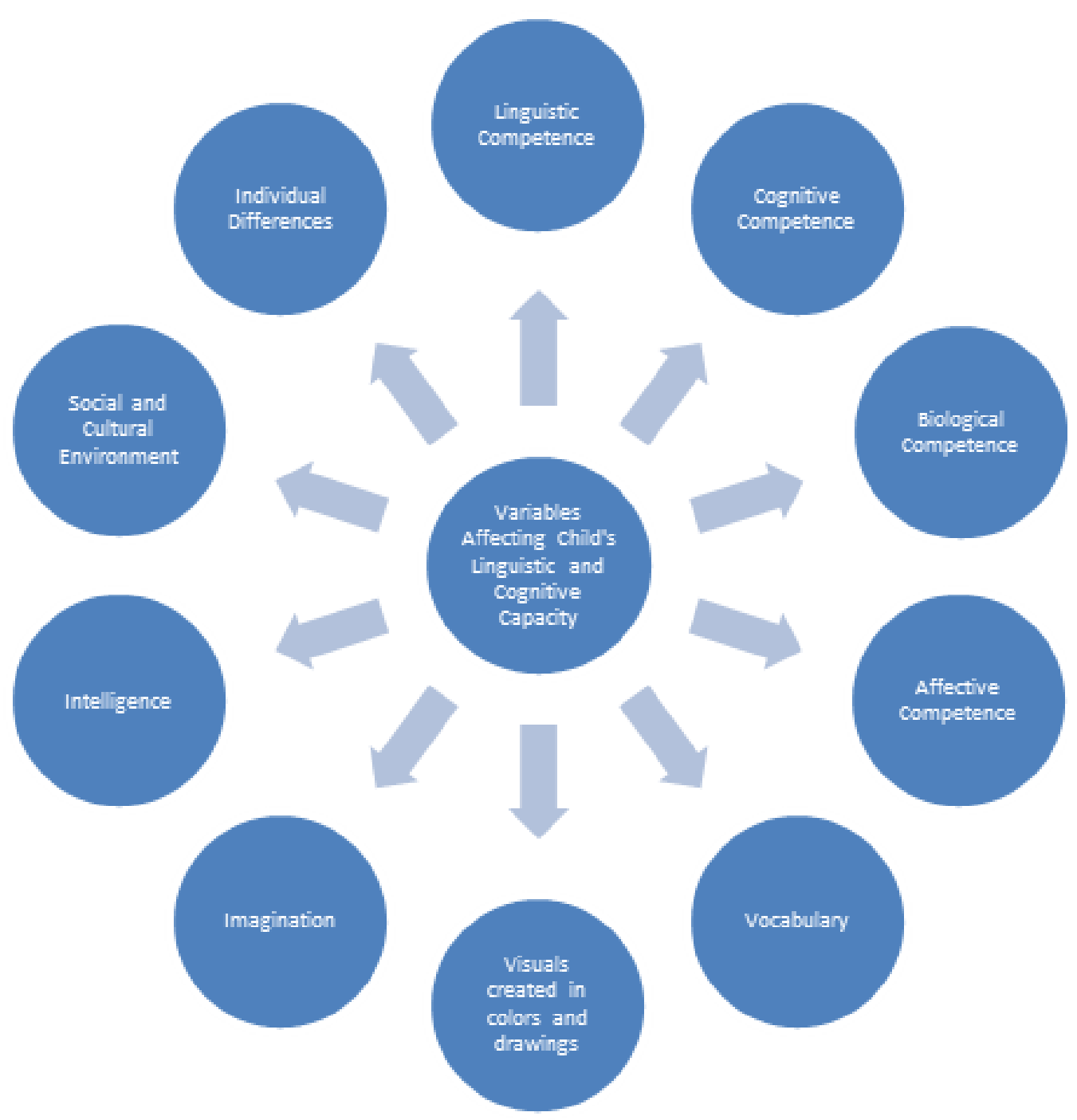

Figure 5. Variables Affecting the Child's Cognitive Capacity [15,16,16,77,78,84].

\section{Conclusions}

Giving a child the responsibility of thinking in an approach appropriate to his developmental stage is among the most basic functions of children's literature. Fulfilling this purpose is possible by ensuring the child's reality is reflected in books. From birth to age six, the relationship between a child and a book is based on the reflection of a child's nature, his interests, his needs, his perspective, and his linguistic and cognitive capacity within the formal and contextual properties of books [90-92]. Therefore, a child's reality should primarily be utilized while preparing books for the $0-6$ age range. Variables that foster the interaction between books and children and are appropriate to the child's reality can make a child an active participant in the process of reading culture.

A child's sincerity, curiosity, effort to comprehend what is obscure, desire for exploration, imagination and creativity, dynamism, enthusiasm, and dislike of advice and commands should also be included in the formal and contextual properties of books for children. In summary, the reflection of a child's nature from birth to age six on the formal and contextual properties of books should be as follows:

- Character: The characters should elicit a desire for visual exploration and curiosity; they should be clear, dynamic, and engage in explicit actions.

- Setting: It should take the child on an adventure using curiosity during phases of conflict and tension within the story.

- Language and Narration: In terms of the visuals and verbal text, it is beneficial to provide clues to solve the mystery in the story and use expressions to arouse curiosity in plain, simple, clear, and easy-to-understand words, sentences, and visuals. Advice and commands should be avoided in narration and it should be presented in a simple style based heavily on action and dynamic statements.

- Plot: It should be formed so that the child can imagine, get excited, explore, and experience adventure.

- Theme: It should be sincerely conveyed with a sensitivity about human beings, life, and nature.

- Cover: It should make children sense contextual clues by directing them to explore and be curious.

- Size: Books in different and unexpected sizes activate 
children's curiosity.

- Layout: It should be in harmony with contrasting and bright colors and dynamic lines that make children curious and want to explore.

- Visuals: Visuals should be very colorful and organized in contrasting colors to foster children's curiosity and exploration.

Children's needs for love, confidence and faith, care and recognition, new experiences, autonomy and responsibility, art, aesthetics, and creativity should be met by books appropriate to their developmental stage. In this respect, the design and content of books for children from birth to age six should be formed in accordance with children's needs as follows:

- Character: The characters should respond to the children's needs for love, confidence, acknowledgment, and care. The characters should seek out and examine new things by asking questions constantly and should meet children's need for new experiences. Finally, the characters' discovery of new and original solutions for problems should contribute to the child learning to think creatively.

- Setting: It should allow children to have new experiences and support them with elements that promote autonomy and responsibility.

- Language and Narration: Visuals and the verbal text should address children in a sincere, loving, and supportive way.

- Plot: It should be related to the love of human beings, nature, and life.

- Theme: It should address love, confidence and faith, care and acceptance, autonomy and responsibility.

- Cover: It should help enhance the aesthetic concept and enjoyment with visuals related to the context and which are appropriate to the children's cognitive level, as well as being plain, clear and comprehensible.

- Size: Books should be of a size that does not conflict with comprehension of what is told in the visuals and verbal text.

- Layout: Elements (colors and their tones, lines, style, pattern, letters, etc.) constituting visuals on the page, as well as the relationship between the main figures and backgrounds, should be in aesthetic harmony to contribute to children's perceptions.

- Visuals: They are expected to make children happy by satisfying their needs for knowing, recognizing, and learning. The colors and lines forming the visuals should also condition the child's aesthetic sensibilities.

Things that children like, enjoy, are interested in, and care about, including unexpected, extraordinary, and new facts, situations, environments, and lives which seem to them extraordinary, supernatural, unusual, mysterious, astonishing, interesting, exciting, funny, and dynamic should be included in the design and content of books. Thus, the following should be taken into account when creating children's books:
- Character: The characters should capture children's interests by being dynamic, interesting, supernatural, and funny. There should be visually personified characters playing games like the child reader, laughing at strange situations, not being able to hide their astonishment, constantly searching for new experiences, and asking questions about what is obscure.

- Setting: There should be storylines embellished by interesting, unusual, and supernatural elements.

- Language and Narration: The verbal text should grab the children's attention through short clauses, action clauses, repetitions, recapitulations, rhymed structures, contrasting and synonymous words, and visual text should be eye-catching with contrasting and bright colors as well as plain and dynamic lines.

- Plot: It should make children understand the realities of human life with entertaining, interesting, funny, astonishing, and supernatural elements.

- Cover: The background-figure relationship should be created in contrasting light and dark colors. Moreover, it should be eye-catching with funny, extraordinary, supernatural, interesting, astonishing, and unexpected elements.

- Size: Books in different sizes that will address children's interests and constantly draw their attention should be created.

- Layout: Items on pages should be structurally and aesthetically pleasing.

- Visuals: Since harmony and disharmony are created by elements such as colors, drawings, spaces, styles, patterns, and size, visuals should be drawn and painted in smooth, curved, and zigzag lines; in contrasting, bright, and vivid colors; with objects and entities of different sizes; in spaces pointing out the story or the character; and in shapes depicting the actions.

The fact that a child in the $0-6$ age range is subjective in his perspective and perception of life and expresses his feelings and ideas sincerely and naturally with idiosyncratic values, and he tries to sense facts by using his imaginary world, should all be taken into consideration in the creation of children's literature. Therefore books for children should not be formed following adults' principles and rules, traditional and contemporary values, enforcing attitudes and statements, stereotyped ideas, multi-minded and sophisticated thinking styles. The fact that reasonableness and rationality are looked for in these books, social rules are given prominence, and the child is constantly brought into real world may repress the child's imaginary, concrete, single-minded, clear, plain, subjective and instant perspective. In brief, children's criteria and evaluations should be preferred, rather than adults' objective criteria and evaluations, while preparing books for children in the abovementioned age range.

- Character: The characters should be depicted verbally and visually by colors, drawings, and words that help the child perceive, sense, think, comprehend, evaluate, 
classify, compare, match, and learn cause and effect relationships.

- Setting: It should be mysterious to foster the child's imagination and intellectual sensibilities.

- Language and Narration: The child's vocabulary should be expanded by using concepts and premises in a simple, clear, comprehensible, and plain style and by supporting this with visuals painted and drawn in color and lines to expand his cognitive capacity.

- Cover: It should include the child interests in the theme and content of the book.

- Size: Animate and inanimate entities in visual texts should differ in size.

- Layout: Items on the page should be clear and comprehensible allowing the child to bring the text easily into his sensory world.

- Visuals: Visual concepts colorfully painted and drawn and appropriate to the child's level should be clear, bright, and dynamic; and visuals reflecting conflicts and actions should give the child the opportunity to imagine and think.

\section{Acknowledgements}

The research reported here derived from author's doctorate dissertation, which was conducted under the supervision of Prof. Dr. Sedat Sever.

\section{REFERENCES}

[1] Dwyer J, Neuman SB. Selecting books for children birth through four: A developmental approach. Early Child Educ J. 2008 Feb 22;35(6):489-94.

[2] Engel S. Children's need to know: Curiosity in schools. Harv Educ Rev. 2011;81(4):625-45.

[3] Hyson M. The emotional development of young children: Building an emotion-centered curriculum. Teachers College Press; 2004.

[4] Murray J. Young children's explorations: Young children's research? Early Child Dev Care. 2012;182(9):1209-25.

[5] Perry BD. Curiosity: The fuel of development. Early Child Today. 2001;15(6):22-4.

[6] Sharp C. Developing young children's creativity: What can we learn from research. 2004;

[7] Trionfi G, Reese E. A good story: Children with imaginary companions create richer narratives. Child Dev. 2009;80(4):1301-13.

[8] Vygotsky LS. Imagination and creativity in childhood. J Russ East Eur Psychol. 2004;42(1):7-97.

[9] Woolf F, Belloli J. Reflect and review: The arts and creativity in early years. Arts council England; 2005.
[10] Cole M, Cole SR, Lightfoot C. The development of children. Macmillan; 2005.

[11] Goswami U. Cognition in children. Psychology Press; 2014.

[12] Pringle MK. The needs of children: A personal perspective. JKP; 1986.

[13] Schneider W, Schumann-Hengsteler R, Sodian B. Young children's cognitive development: Interrelationships among executive functioning, working memory, verbal ability, and theory of mind. Psychology Press; 2014.

[14] Sroufe LA. Emotional development: The organization of emotional life in the early years. Cambridge University Press; 1997.

[15] Sever S. Çocuk edebiyatı ve okuma kültürü. Alsancak-Konak, İzmir: Tudem; 2013.

[16] Piaget J. The psychology of the child. New York: Basic Books; 2004.

[17] Lee V, Gupta P das. Children's cognitive and language development. 1996;

[18] Stearns PN. Childhood in world history. New York, NY: Routledge; 2011.

[19] Piaget J. The language and thought of the child. New York: Routledge; 2013.

[20] Gopnik A, Meltzoff AN, Kuhl PK. The scientist in the crib: What early learning tells us about the mind. Harper Paperbacks; 2000.

[21] Kashdan TB, Silvia PJ. Curiosity and interest: The benefits of thriving on novelty and challenge. Oxf Handb Posit Psychol. 2009;2:367-74.

[22] Olmsted S. Imagine childhood: exploring the world through nature, imagination, and play. Boston: Roost Books; 2012.

[23] Karwowski M. Did curiosity kill the cat? Relationship between trait curiosity, creative self-efficacy and creative personal identity. Eur J Psychol. 2012;8(4):547-58.

[24] Honomichl RD, Chen Z. The role of guidance in children's discovery learning. Wiley Interdiscip Rev Cogn Sci. 2012;3(6):615-22.

[25] Casper V, Theilheimer R. Early childhood education: learning together. New York: McGraw-Hill Higher Education; 2010 .

[26] Baumer S, Ferholt B, Lecusay R. Promoting narrative competence through adult-child joint pretense: Lessons from the Scandinavian educational practice of playworld. Cogn Dev. 2005;20(4):576-90.

[27] Diachenko OM. On major developments in preschoolers' imagination. Int J Early Years Educ. 2011;19(1):19-25.

[28] Gleason TR. Social provisions of real and imaginary relationships in early childhood. Dev Psychol. 2002;38(6):979.

[29] Harris PL. The work of the imagination. Blackwell Publishing; 2000.

[30] Astington JW, Harris PL, Olson DR. Developing theories of mind. CUP Archive; 1990. 
[31] Pons F, Harris PL, de Rosnay M. Emotion comprehension between 3 and 11 years: Developmental periods and hierarchical organization. Eur J Dev Psychol. 2004;1(2):127-52.

[32] Benson JB, Haith MM. Social and emotional development in infancy and early childhood. Academic Press; 2010.

[33] Flavell JH, Flavell ER, Green FL. Development of children's understanding of connections between thinking and feeling. Psychol Sci. 2001;12(5):430-2.

[34] Larkin - Lieffers PA. Images of childhood and the implied reader in young children's information books. Literacy. 2010;44(2):76-82.

[35] James A, Prout A. Constructing and reconstructing childhood: Contemporary issues in the sociological study of childhood. Routledge; 2015.

[36] Walkerdine V. Developmental psychology and the study of childhood. Child Crit Concepts Sociol. 2005;3:13-25.

[37] Widen SC, Russell JA. Young children's understanding of other's emotions. Handb Emot. 2008;3:348-63.

[38] Arnold MB. Feelings and emotions: The Loyola symposium. Academic Press; 2013.

[39] Apter MJ. Danger: Our quest for excitement. Oneworld Pubns Ltd; 2007.

[40] Ekman P. Emotions revealed: Recognizing faces and feelings to improve communication and emotional life. Macmillan; 2007.

[41] Sahin E, Barut Y, Ersanlı E. Parental education level positively affects self-esteem of Turkish adolescents. J Educ Pract. 2013;4(20):87-97.

[42] Sahin E, Barut Y, Ersanlı E. Sociodemographic variables in relation to social appearance anxiety in adolescents. Int J Soc Sci. 2013;15(1):56-63.

[43] Şahin E. Bazı değișkenlere göre ilköğretim ikinci kademe öğrencilerinin benlik saygıları ve sosyal görünüş kaygıları [Master Thesis]. [Samsun]: Ondokuz Mayıs Üniversitesi, Eğitim Bilimleri Enstitüsü; 2012.

[44] Collado FY. The role of spontaneous drawing in the development of children in the early childhood settings. Pap Print US Dep Educ. 1999;1-16.

[45] Langan M. The congested concept of needs. In: Langan M, editor. Needs, right and risk. London, England: The Open University Press; 1998.

[46] $\mathrm{Hu}$ Y. Constructions of children's needs in informal kinship care in rural China. 2013;

[47] Maslow AH. Toward a psychology of being. New York: Van Nostrand; 1968.

[48] Pringle MK. The needs of children a personal perspective. London: Hutchinson; 1986.

[49] Cowden M. What's love got to do with it? Why a child does not have a right to be loved. Crit Rev Int Soc Polit Philos. 2012;15(3):325-45.

[50] Liao SM. The right of children to be loved. J Polit Philos. 2006;14(4):420-40.
[51] Horwath J. The child's world, assessing children in need. In: Horwath J, editor. Assesing the world of the child in need: background and context. London: Jessica Kingsley Publishers.; 2001.

[52] Bower L. Everyday learning about imagination. Watson, ACT: Early Childhood Australia Inc.; 2005.

[53] Thompson RA. The development of the person: Social understanding, relationships, conscience, self. In: Eisenberg N, Damon W, Lerner RM, editors. Handbook of child psychology: Vol 3, Social, emotional, and personality development (6th ed). Hoboken, NJ, US: John Wiley \& Sons Inc; 2006. p. 24-98.

[54] Hupcey JE, Penrod J, Morse JM, Mitcham C. An exploration and advancement of the concept of trust. J Adv Nurs. 2001;36(2):282-93.

[55] Şahin E, Barut Y, Ersanlı E, Kumcağız H. Self-esteem and social appearance anxiety: An investigation of secondary school students. J Basic Appl Sci Res. 2014;4:152-9.

[56] Lindon J. Child care and early education: Good practice to support young children and their families. Cengage Learning EMEA; 2003.

[57] Beard CM, Wilson JP. Experiential learning: A best practice handbook for educators and trainers. Kogan Page Publishers; 2006.

[58] Gibson EJ, Pick AD. An ecological approach to perceptual learning and development. Oxford University Press; 2000.

[59] Boud D, Cohen R, Walker D. Using experience for learning. McGraw-Hill Education (UK); 1993.

[60] İpşiroğlu N. Gelin çocuklar birlikte düşünelim. İzmir: Tudem; 2013.

[61] Kağıtçıbaşı Ç, Öztürk Ş. Benlik, aile ve insan gelişimi: kültürel psikoloji. İstanbul: Koç Üniversitesi Yayınları; 2010.

[62] Burger JM. Personality. 9th ed. Stamford: Cengage Learning; 2015.

[63] Arnold MB. Feelings and emotions: The Loyola Symposium. New York: Academic Press; 2013.

[64] Striker S. Çocuklarda sanat eğitimi. İstanbul: Epsilon; 2005.

[65] Koster JB. Growing artists: teaching the arts to young children. Clifton Park, NY: Thomson Delmar Learning; 2009.

[66] Mayesky M. Creative activities for young children. Albany: Delmar/Thomson Learning; 2002.

[67] Kagan J. Motives and development. J Pers Soc Psychol. 1972;22(1):51-66

[68] Hidi S. Interest: A unique motivational variable. Educ Res Rev. 2006;1(2):69-82.

[69] Meyer DK, Turner JC. Discovering emotion in classroom motivation research. Educ Psychol. 2002;37(2):107-14.

[70] Krapp A, Hidi S, Ann K. Interest, learning, and development. Interest, learning, Renninger KA, Hidi S, Krapp A, editors. The role of interest in learning and development. Hillsdale, NJ, England: Lawrence Erlbaum Associates, Inc; 1992. p. $3-25$.

[71] Chen A, Darst PW, Pangrazi RP. An examination of situational interest and its sources. Br J Educ Psychol. 2001 Sep 1;71(3):383-400. 
[72] Yavuzer H. Çocuk psikolojisi. İstanbul: Remzi Kitabevi; 2007.

[73] Yörükoğlu A. Gençlik çağı: Ruh sağlığı ve ruhsal sorunları. Ankara: Özgür Yayın Dağıtım; 1990.

[74] Şahin E, Ersanlı E, Kumcağız H, Barut Y, Ak E. Sociodemographic differences in empathic tendency: A sample of religious high school students. J Stud Educ. 2014;4(4):1-11.

[75] Dilidüzgün S. Çağdaş çocuk yazını: yazın eğitimine atılan ilk adım. İstanbul: Morpa Külẗur Yayınları; 2004.

[76] Vygotski LS. Mind in society: the development of higher psychological processes. Cambridge: Harvard University Press; 1978.

[77] Gander MJ, Gardiner HW. Çocuk ve ergen gelişimi. Ankara: İmge Kitabevi; 2010.

[78] Miller PH. Theories of developmental psychology. New York: Worth Publishers; 2011.

[79] Şahin E, Topkaya N. Factor structure of the Social Appearance Anxiety Scale in Turkish early adolescents. Univers J Educ Res. 2015;3(8):513-9.

[80] Pieget J. The child's conception of the world. New York: Routledge; 2013.

[81] Beaney M. Imagination and creativity. Open University Milton Keynes, UK; 2005.

[82] Ackermann E. The whole child development guide. LEGO Learn Inst. 2004;

[83] Honomichl RD, Chen Z. The role of guidance in children's discovery learning. Wiley Interdiscip Rev Cogn Sci. 2012 Nov 1;3(6):615-22.

[84] Boyd DR, Bee HL. The Growing Child. Allyn \& Bacon; 2010.

[85] Anisfeld M. Language development from birth to three.
Psychology Press; 2014.

[86] Berk L. E. Child Development, 9/e. 2012;

[87] Davies D. Child development: A practitioner's guide. Guilford Press; 2010.

[88] Bowlby J. Attachment and loss. Separation: Anxiety and anger (Vol. 2). New York: Basic Books; 1973.

[89] Tobin D, Nadalin E, Munroe-Chandler K, Hall C. Children's active play imagery. Psychol Sport Exerc. 2013;14(3):371-8.

[90] Çer E. Edebiyatta çocuk gerçekliği ve çocuğa görelik ilkelerinin incelenmesi [The study of child reality and relation to child principles in literature] [Doctoral Thesis]. [Ankara]: Ankara Üniversitesi; 2014.

[91] Çer, E. Çocuk edebiyatı: 0-6 yaş çocuk kitaplarında çocuk gerçekliği ve çocuğa görelik. Ankara: Eğiten Kitap; 2016a

[92] Çer, E. Preparing for books children from birth to six: The approach of appropriateness for the child. Journal of Education and Practice. 2016b;7(6), 78-99.

[93] Çer, E. One step forward and two steps back: A study of the image of woman in the 100 basic works of literature in Turkey. Universal Journal of Educational Research. 2015;3(12), 1008-1014.

[94] Gençoğlu C, Topkaya N, Şahin E, Kaya L. Attachment styles as predictors of stigma tendency in adults. Educational Process: International Journal. 2016;5(1):7-21.

[95] Aslan, C. (2011). Yazınsal çocuk kitaplarında neler olmall, neler olmamalı? Okuma kültürü ve söz varlığının geliștirilmesi çalıștayı. Ankara: Talim ve Terbiye Kurulu Başkanlığı Yayınları.

[96] Aslan, C. (2013a). Çocuk edebiyatı yapıtlarının temel işlevleri. Ĕgitimci Ögretmen Dergisi, 17, 6-9.

[97] Aslan, C. (2013b). Duyarlık ve düşünceyi geliştirmede çocuk/gençlik edebiyatı. Çocuk Çocuk Anne Baba Eğitimci Dergisi, 12, 29-32. 